УДК 621.436

\title{
ПОЛІПШЕННЯ ХАРАКТЕРИСТИК ФУНКЦІОНУВАННЯ МЕХАНІЗМУ ГАЗОРОЗПОДІЛУ ЕНЕРГЕТИЧНИХ УСТАНОВОК ТЕПЛОВОЗІВ 3 ДИЗЕЛЕМ Д49 ЗА РАХУНОК ВИКОРИСТАННЯ УДОСКОНАЛЕНИХ РОЗПОДІЛЬНИХ ВАЛІВ
}

\author{
К-т техн. наук К.В. Іванченко
}

\section{УЛУЧШЕНИЕ ХАРАКТЕРИСТИК ФУНКЦИОНИРОВАНИЯ МЕХАНИЗМА ГАЗОРАСПРЕДЕЛЕНИЯ ЭНЕРГЕТИЧЕСКИХ УСТАНОВОК ТЕПЛОВОЗОВ С ДИЗЕЛЕМ Д49 ЗА СЧЕТ ИСПОЛЬЗОВАНИЯ УСОВЕРШЕНСТВОВАННЫХ РАСПРЕДЕЛИТЕЛЬНЫХ ВАЛОВ}

\section{К-т техн. наук К.В. Иванченко \\ THE IMPROVEMENT OF THE CHARACTERISTICS OF FUNCTIONING OF THE DIESEL POWER PLANTS D49 VALVE CONTROL AT THE EXPENSE OF MODERNIZED CAMSHAFTS}

\author{
Cand. of techn. science K. Ivanchenko
}

В роботі наведено результати досліджень, спрямованих на поліпшення характеристик функиіонування кулачкового механізму газорозподілу енергетичних установок тепловозів з дизелем Д49 за рахунок використання удосконалених розподільних валів з новими патентозахищеними кулачками приводу впускних $i$ випускних клапанів. Виявлено, щчо використання таких розподільних валів в конструкції забезпечує високі значення часу-перерізу клапанів порівняно з серійними тангенціальними кулачками, безударну динаміку клапанного приводу при виконанні усіх вимог та обмежень, а саме зменшення рівнів максимальних контактних напружень в парах «кулачок-ролик итовхача», щзо забезпечує збільшення міџңності, підвищення надійності та зменшення зносів робочих поверхонь контактуючих деталей.

Ключові слова: енергетична установка тепловозу; розподільний вал; кулачковий механізм газорозподілу, час-переріз.

В работе приведены результаты исследований, направленных на улучшение характеристик функиионирования кулачкового механизма газораспределения энергетических установок тепловозов $c$ дизелем Д49 за сет использования усовершенствованных распределительных валов с новыми патентозащищенными кулачками привода впускных и выпускных клапанов. Показано, что использование таких распределительных валов в конструкции обеспечивает высокие значения время-сечения клапанов в сравнении с серийными тангенщиальныли кулачками, а также безударную динамику клапанного привода при выполнении всех условий и ограничений, что обеспечивает увеличение прочности, повышение надежности и уменьшение износов рабочих поверхностей контактирующих деталей.

Ключевые слова: энергетическая установка тепловоза, распределительный вал, кулачковый механизм распределения, время-сечение.

The article presents the results of research aimed at improving performance cam mechanism timing operation of power plants with diesel D49 at the expense of use of improved camshafts with new proprietary cams drive intake and exhaust valves. It is shown that use of these camshafts in the construction provides high value of the valves time-section compared with serial tangential cams and unstressed dynamics of the valve drive with all requirements and restrictions, such as reducing the levels of maximum contact stresses in pairs "cam pusher", which increase strength, reliability and reduce wear of working surfaces in contact details.

Keywords: diesel power plant, camshaft, cam timing, time-section of the valve. 


\section{Постановка проблеми i аналіз} останніх досліджень $\quad$ н напрямку їі вирішення.

Одним 3 перспективних напрямків поліпшення техніко-економічних показників енергетичних установок тепловозів 3 дизелем Д49 (ЕУТ Д49) є їх модернізація на основі удосконалення конструкції кулачкових механізмів газорозподілу (КМГР), оскільки конструкція розподільних валів визначає протікання процесів газообміну, які в свою чергу оказують значний вплив на якість робочих процесів. При проектуванні розподільних валів (РВ) найбільша складність полягає у проведенні процедури профілювання безударних газорозподільних кулачків, які б забезпечували не тільки задовільні динамічні характеристики КМГР, чому відповідає відсутність розривів у кінематичному ланцюзі клапанного приводу, виконання вимог міцності деталей, конструктивних i технологічних обмежень, але і максимально можливі значення часу - перерізу (ЧП) клапанів за умов якісного протікання робочого процесу в циліндрах двигуна, які головним чином визначаються саме профілем газорозподільних кулачків.

В конструкції КМГР ЕУТ Д49 застосовуються тангенціальні кулачки, які характеризуються більш високою в порівнянні 3 іншими ефективністю за ЧП клапанів. Але при їх використанні в механізмі мають місце прояви незадовільної динаміки, які можуть привести до негативних наслідків, що свідчить про недоцільність їх застосування в конструкції розподільних валів ЕУТ Д49.

Представлені матеріали обгрунтували актуальність робіт, спрямованих на удосконалення конструкції розподільних валів енергетичних установок з дизелем Д49 на основі запропонованих технологій проектування.

Мета статті і викладення основного матеріалу.

Стаття присвячена висвітленню результатів досліджень, спрямованих на поліпшення характеристик функціонування кулачкового механізму газорозподілу ЕУТ Д49 магістрального тепловозу за рахунок використання удосконалених розподільних валів з новими кулачками приводу впускних (ВПК) і випускних (ВИПК) клапанів.

Основою проведення таких робіт $\epsilon$ запропонований новий метод профілювання високоефективних безударних газорозподільних кулачків, які захищені патентом України на винахід $[1,2,3,4]$.

$$
\text { Першим етапом робіт було }
$$

визначення основних параметрів базової кривої прискорень штовхача приводу впускних та випускних клапанів. Отримані результати дозволили провести комплексні дослідження 3 моделювання характеристик функціонування кулачкових механізмів газорозподілу ЕУТ Д49 з удосконаленим розподіленим валом, а також виконати оцінювання показників механічної напруженості основних елементів конструкції клапанного приводу.

На рис.1 представлені кінематичні характеристики роликових коромислових штовхачів, що взаємодіють 3 запропонованими кулачками, в порівнянні 3 характеристиками, отриманими для серійних тангенціальних кулачків.

Їх аналіз показав, що при застосуванні удосконалених розподільних валів забезпечується суттєе збільшення коефіцієнтів $\eta_{\Pi}$ кулачкових механізмів газорозподілу ЕУТ Д49.

Так, для кулачкового механізму приводу ВИПК величина коефіцієнту повноти діаграми переміщень штовхача складає $\eta_{\Pi}=0,66$ (для тангенціального кулачка $\left.\eta_{\Pi}=0,59\right)$, а для механізму приводу ВПК - $\eta_{\Pi}=0,64 \quad$ (для тангенціального кулачка $\eta_{\Pi}=0,57$ ).

Представлені кінематичні характеристики штовхачів стали основою для розрахунків координат робочих (конструктивних) профілів нових патентозахищених кулачків приводу впускних і випускних клапанів енергетичних установок тепловозів 3 дизелем Д49. Також було отримано таблиці координат, які $\epsilon$ базою для виготовлення запропонованих газорозподільних кулачків в умовах залізничних підприємств України. 


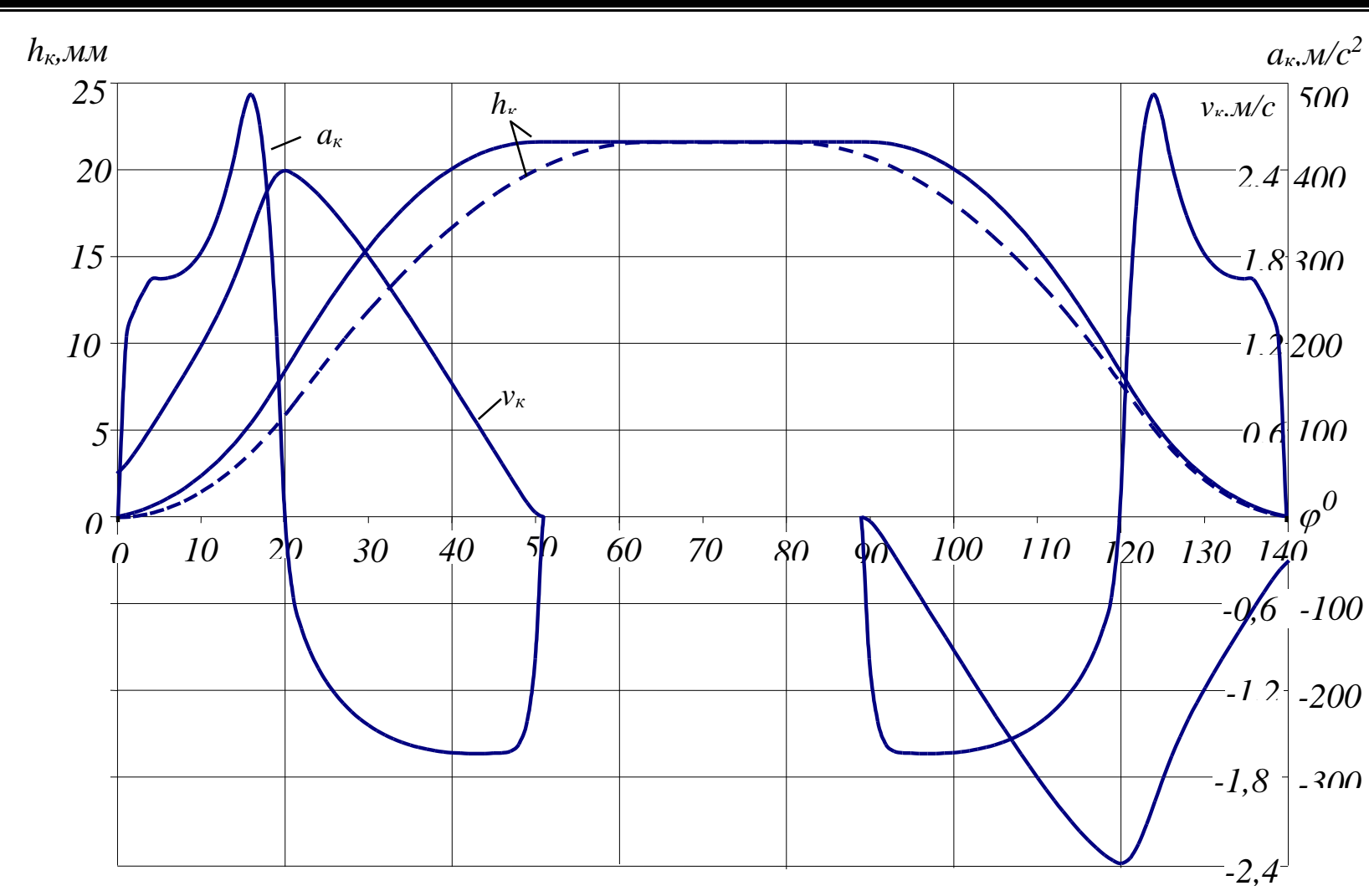

Рисунок - 1 Кінематичні характеристики випускних клапанів ЕУТ Д49:

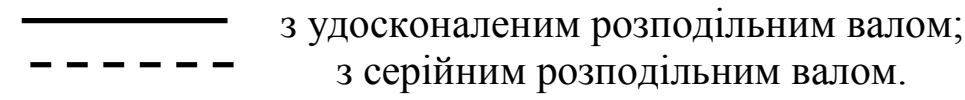

Аналіз результатів розрахунків кінематичних характеристик ВИПК і ВПК показав, що при застосуванні удосконаленого розподільного валу часпереріз впускних i випускних клапанів збільшується на 18-21\%. Такі результати свідчать, що при використанні нових газорозподільних кулачків можливе зниження середньоексплуатаційних витрат палива $b_{c e}$ енергетичних установок тепловозів 3 дизелем Д49 на $3 \ldots 5$ г/(екBm·год). [5, 6].

Наступний етап комплексного розрахункового дослідження передбачав моделювання динамічних характеристик кулачкових механізмів приводу ВПК i ВИПК, результати якого представлені на рис.2.

3 графіків видно, що при використанні удосконалених РВ забезпечується умова безрозривності кінематичних ланцюгів механізмів приводу ВПК і ВИПК $z>0$.

3 метою оцінювання умов посадки клапанів на сідло, а також механічної напруженості основних елементів КМГР ЕУТ Д49 при використанні удосконалених PB, на наступному етапі виконувались розрахунки дійсних закономірностей руху впускних i випускних клапанів. Узагальнення результатів комплексних досліджень 3 моделювання характеристик функціонування кулачкових механізмів газорозподілу ЕУТ Д49 з удосконаленими РВ представлено в табл.1.

\section{Висновки i}

\section{використання.}

Використання в конструкції ЕУТ Д49 розподільних валів 3 новими безударними газорозподільними кулачками забезпечує високі значення ЧП клапанів, безударну динаміку клапанного приводу при виконанні усіх вимог та обмежень. Так, в порівнянні 3 тангенціальними кулачками, значення $\eta_{\Pi}$ збільшується на $12 \%$, що забезпечує збільшення ЧП впускних $і$ випускних клапанів на $18-21 \%$ i зниження середньоексплуатаціних витрат палива на $3 . .5$ г/(екBm-год); рівні максимальних контактних напружень в парах «кулачок- 
ролик штовхача» зменшуються на $15 \%$ для впускних клапанів та на $30 \%$ для випускних, що забезпечує збільшення міцності, підвищення надійності та зменшення зносів робочих поверхонь контактуючих деталей.
Це обгрунтовує доцільність виготовлення дослідних розподільних валів 3 запропонованими кулачками 3 метою експериментальної перевірки характеристик ЕУТ Д49 в експлуатації.

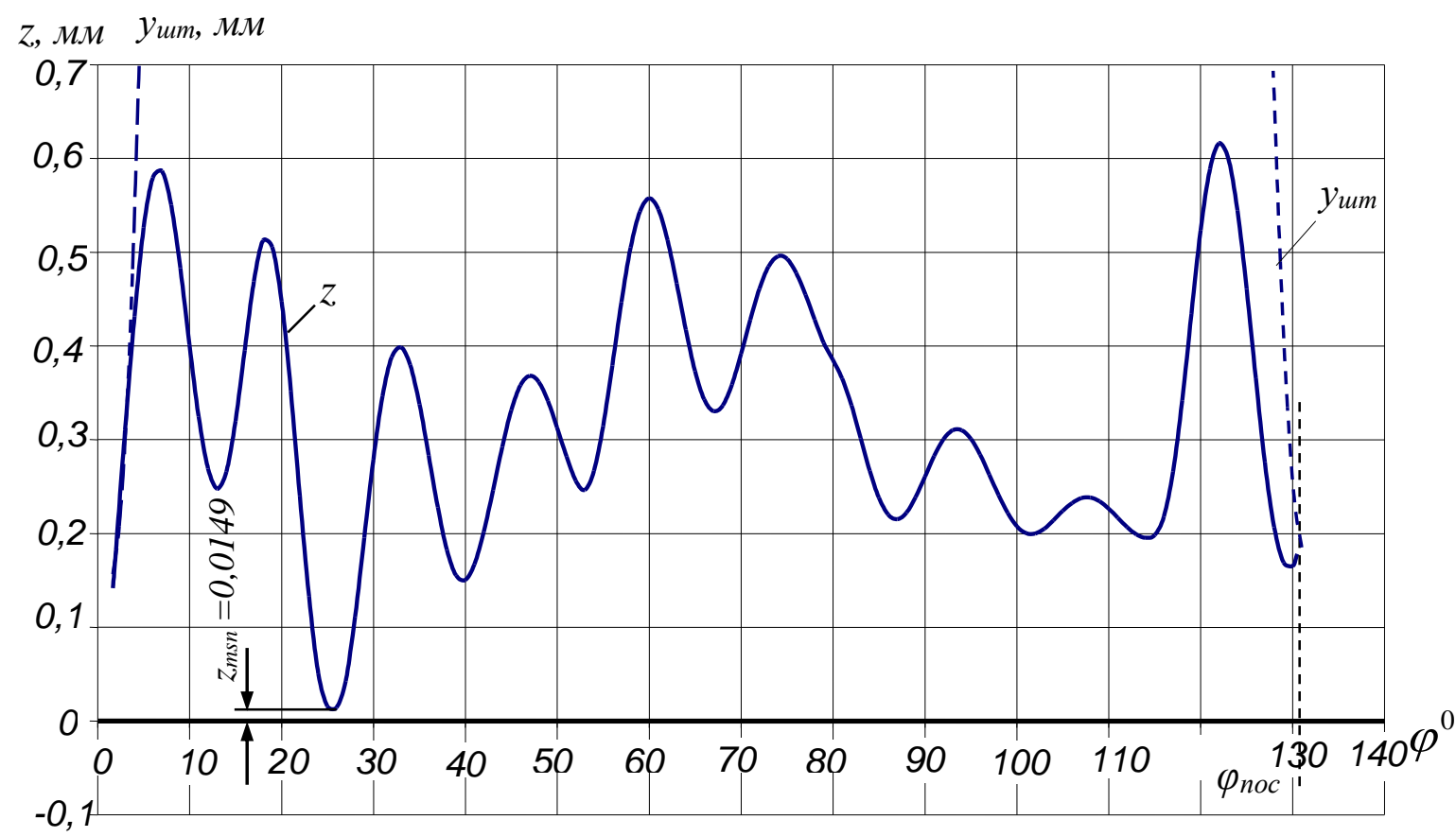

Рисунок - 2 Динамічні характеристики механізму приводу впускних клапанів ЕУТ Д49 з удосконаленим розподільним валом

Таблиця 1

Результати комплексних досліджень з моделювання характеристик функціонування КМГР ЕУТ Д49 з удосконаленими розподільним валом

\begin{tabular}{|c|c|c|c|c|}
\hline \multirow[b]{2}{*}{ Контрольований показник } & \multirow[b]{2}{*}{$\begin{array}{c}\text { Познач } \\
\text { ення }\end{array}$} & \multirow[b]{2}{*}{$\begin{array}{l}\text { Розмір } \\
\text { ність }\end{array}$} & \multicolumn{2}{|c|}{ Величина показника } \\
\hline & & & $\begin{array}{c}\text { Кулачок } \\
\text { приводу ВИПК } \\
\text { новий/танг. }\end{array}$ & $\begin{array}{c}\text { Кулачок } \\
\text { приводу ВПК } \\
\text { новий/танг. }\end{array}$ \\
\hline $\begin{array}{l}\text { Мінімальний } \\
\text { увігнутої ділянки про }\end{array}$ & $R_{\text {min }}^{\kappa p}$ & $M M$ & $-170,8 /-$ & $-170,9 /-$ \\
\hline $\begin{array}{l}\text { Максимальні тимчасові контактні } \\
\text { напруження в парі «кулачок -ролик } \\
\text { штовхача» }\end{array}$ & $\sigma_{\operatorname{Hmax}}$ & МПа & $1336 / 1773$ & $882 / 1007$ \\
\hline $\begin{array}{l}\text { Мінімальний коефіцієнт запасу } \\
\text { стійкості штанги. }\end{array}$ & $n_{\min }$ & - & $3,01 / 2,56$ & - \\
\hline $\begin{array}{l}\text { Максимальний кут тиску кулачка на } \\
\text { штовхач }\end{array}$ & $\beta_{\max }$ & Градус & $20,2 / 23$ & $17,8 / 23$ \\
\hline Швидкість посадки клапанів на сідло & $v_{0}$ & $M / C$ & $0,52 / 0,72$ & $0,32 / 0,48$ \\
\hline $\begin{array}{l}\text { Мінімальний } \quad \text { коефіцієнт запасу } \\
\text { клапаних пружин за силами інерції }\end{array}$ & $k_{3 n}$ & - & $1,52 / 1,3$ & $1,6 / 1,45$ \\
\hline $\begin{array}{l}\text { Мінімальна узагальнена деформація } \\
\text { приводу }\end{array}$ & $z \min$ & $M M$ & $0,197 / 0,38$ & $0,0149 /-0,039$ \\
\hline $\begin{array}{l}\text { Величина } \quad \text { коефіцієнту } \\
\text { діаграми переміщень штовхача }\end{array}$ & $\eta_{\Pi}$ & - & $0,66 / 0,59$ & $0,64 / 0,57$ \\
\hline
\end{tabular}




\section{Список використаних джерел}

1. Мороз В.I. Новий підхід до динамічного синтезу безударних профілів газорозподільних кулачків транспортних дизелів / В.І. Мороз, О.В. Братченко, К.В. Астахова // Зб. наук. праць УкрДАЗТ. - Харків, 2008. - Вип.99. - С. 242-249.

2. Мороз В.I. Новий підхід до профілювання газорозподільних кулачків форсованих тепловозних дизелів / В.І.Мороз, О.В.Братченко, О.А. Логвіненко, К.В. Астахова // Зб. наук. праць УкрДАЗТ. - Харків, 2010. - Вип. 119. - С.110-116.

3. Пат. 90952 Україна, MПК F01L 1/08. Кулачок механізму газорозподілу / Мороз B.I., Братченко О.В., Астахова К.В., Тіщенко В.С.; заявник та патентовласник Українська державна академія залізничного транспорту. - № а 200813509; заявл. 24.11.08; опубл. 10.06.2010, Бюл. № 11.

4. Мороз В.І. Розроблення узагальненого формалізованого описання задачі динамічного синтезу безударних профілів кулачків привода клапанів транспортних дизелів / В.І. Мороз, К.В. Астахова // Зб. наук. праць УкрДАЗТ. - Харків, 2009. - Вип. 111. - С. 82-93.

5. Мороз В.I. Оцінка резервів поліпшення експлуатаційних показників тепловозних дизелів типу Д80 за рахунок модернізації механізму привода клапанів / B.I. Мороз, О.В. Братченко, О.А. Логвіненко// Підвищення експлуатаційної ефективності тягового рухомого складу залізниць: Міжвуз.зб.наук.праць ХарДАЗТ. - Харків, 2000. - Вип. 41. - C.10-13.

6. Двигуни внутрішнього згоряння: Серія підручників у 6 томах. Т.2. Доводка конструкцій форсованих двигунів наземних транспортних машин. / За редакцією проф. А.П. Марченка, засл. діяча науки України проф. А.Ф. Шеховцова - Харків: Видавн. центр НТУ "ХПІ", 2004. - 365 c.

$$
\text { Рецензент д-р техн. наук, профессор О.В. Устенко }
$$

Іванченко Ксенія Вікторівна, кандидат технічних наук, доцент кафедри механіки $і$ проектування машин Українська державна академія залізничного транспорту. Тел.: (057)730-10-52. E-mail: xeniya.ivanchenko@gmail.com

Ivanchenko Kseniya Viktorivna, cand. of techn. science, lecturer, department Mechanics and Machine Design, Ukrainian State Academy of Railway Transport. Tel.: (057)730-10-52. E-mail: xeniya.ivanchenko@gmail.com 